\title{
Using a New Acid-tolerant Bacteria to Improve Sludge Management
}

\section{The use of a new bacteria could transform pollutant removal and resource and energy recovery in wastewater treatment plants}

\section{ABSTRACT}

Wastewater treatment plants (WWTPs) are evolving from pollutant removal facilities to energy and resource recovery factories. This paper introduces an acidic activated-sludge process, which expands the operational $\mathrm{pH}$ from a neutral $(\sim 7)$ to acidic range (2-6), using a new ammonia-oxidising bacterium $\mathrm{Ca}$. Nitrosoglobus. The acidic activated-sludge process enables nitrogen removal via anammox, which does not require organic carbon and allows the organics in sewage to be captured and recovered as biomethane. The acidic activated-sludge process also reduces solids concentration, inactivates pathogens, and removes metals from sludge, generating Class A biosolids which qualify for unrestricted agricultural reuse. Overall, the established acidic activated-sludge process opens up new opportunities to address the main challenges confronted by WWTPs, i.e., attaining satisfactory pollutant removal while maximising energy and resource recovery from sewage.

\section{PARADIGM SHIFT FROM WASTEWATER \\ TREATMENT PLANTS (WWTPS) TO WATER RESOURCE RECOVERY FACILITIES (WRRFS)}

Wastewater treatment plants (WWTPs) are evolving from traditional pollutant removal facilities to emerging resource recovery factories. The most valuable resources in sewage, apart from water, include nutrients (nitrogen and phosphorus) and chemical energy embedded in organic carbon (Figure 1). However, in current WWTPs the organic carbon is usually oxidised to $\mathrm{CO}_{2}$ which not only wastes the embedded energy but also consumes huge amounts of electricity for aeration.

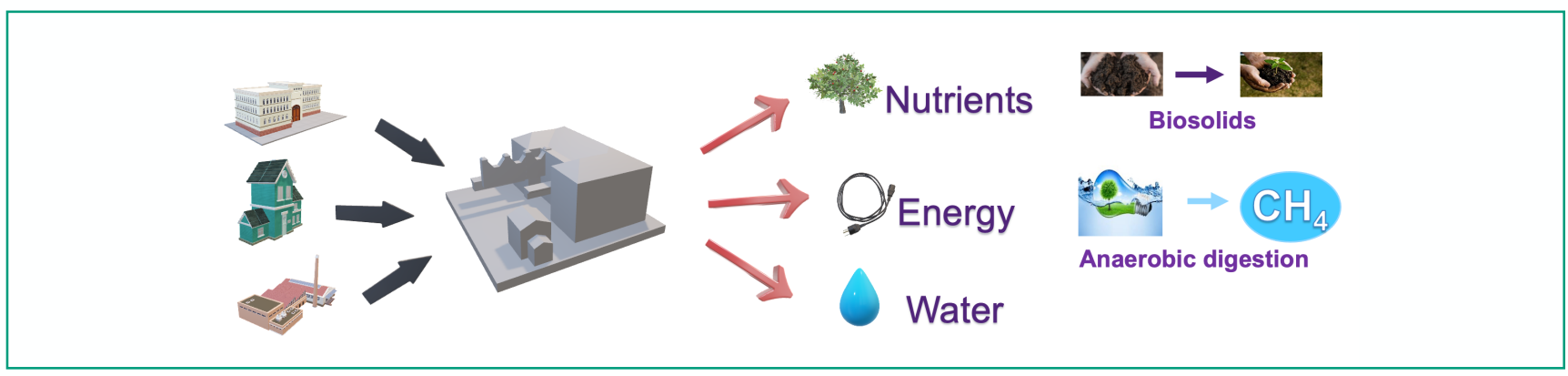

Figure 1: Wastewater treatment plants (WWTPs) are shifting to water resource recovery facilities (WRRFs). The valuable resources in wastewater include nutrients (nitrogen and phosphorus), energy, and water. 
Upfront organics capture units (e.g. fine screens, high-rate activated sludge (HRAS), or chemically-enhanced primary treatment (CEPT)) will significantly enhance the potential for energy recovery (Figure 2). However, removing significant amounts of organics impacts the ability of the downstream activated sludge process to effectively reduce nitrogen levels in the wastewater via the traditional nitrificationdenitrification process. This limitation is negated with an autotrophic nitrogen removal process, referred to as partial nitritation and anaerobic ammonium oxidation (anammox) (PN/A) ${ }^{3}$. However, the implementation of PN/A in the lowstrength (20-60 $\left.\mathrm{mg} \mathrm{L}^{-1}\right)$ sewage treatment is still in its infancy. One of the key challenges is to selectively suppress nitrite-oxidising bacteria (NOB), which would otherwise oxidise nitrite to nitrate that cannot be removed via anammox. Despite considerable efforts and the significant progress achieved to date, the difficulty of achieving stable NOB suppression is still hindering the full-scale PN/A application for low-strength domestic wastewater treatment 4,5 .
With respect to the solids stream, the critical aspect is in relation to the high cost for sludge handling. Sludge transport and disposal can be up to $60 \%$ of the overall costs in a WWTP ${ }^{6}$. Cost savings can be achieved through reducing sludge volume and improving sludge quality. However, the sludge treatment technology in the aforementioned process (Figure 2), i.e. AD, can only achieve around $30 \%$ volatile solids reduction ${ }^{7}$. In addition, without thermal treatment, anaerobically-digested sludge (AD sludge) is normally graded as Class B (i.e., biologically stable, but with odour potential and pathogens present), which does not allow for unrestricted public contact (Australian Biosolids guidelines). AD sludge will also contain metal contaminates, which are tightly regulated by environmental authorities, e.g. zinc and copper. These will limit biosolids use in terms of the application rate, crop types, operator competence, and application zones (Australian Biosolids guidelines). Further treatment of AD sludge is therefore beneficial for a cost-effective and wide use of biosolids.

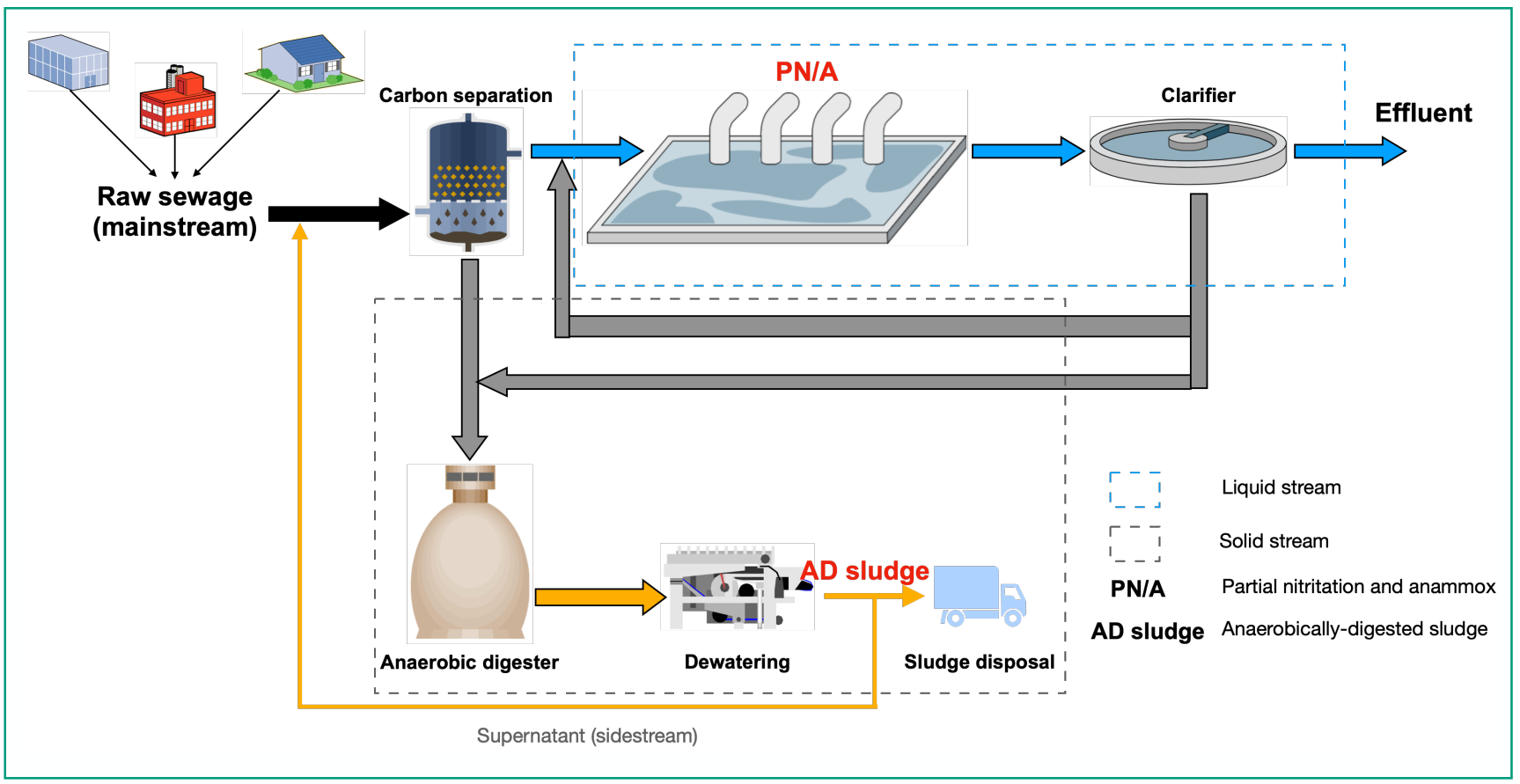

Figure 2: An energy-efficient and cost-effective sewage treatment process design 


\section{A NEW AMMONIA- OXIDISING BACTERIA (AOB) CANDIDATUS (Ca.) NITROSOGLOBUS AS THE GAME-CHANGER}

The acidic activated-sludge process has opened up a new path to address the aforementioned challenges. This novel process operates at acidic conditions (i.e. $\mathrm{pH} 4-5$ ), enables stable NOB suppression (Li et al., 2020), reduces and stabilises excess sludge (Duan et al., 2019), and solubilises heavy metals from sludge.

The low-pH in the acidic activated-sludge process is generated and self-sustained by microbial ammonia oxidation (Equation 1). The oxidation of one-mole ammonium $\left(\mathrm{NH}^{+}\right)$generates two-mole protons $\left(\mathrm{H}^{+}\right)$, which causes lowering of the $\mathrm{pH}$. The $\mathrm{pH}$ could drop to below 5.0 in a system where alkalinity in the wastewater/sludge is inadequate to buffer the generated protons (Li et al., 2020). Meanwhile, ammonia oxidation also produces nitrite, a fraction of which is protonated to form FNA (i.e. $\mathrm{HNO}_{2}$ ), particularly at acidic conditions. The generated FNA inhibits NOB, thereby stopping nitrite from being further oxidised to nitrate. As such, the products of ammonium oxidation, i.e. nitrite and its protonated form (FNA), are self-sustained in an acidic activated-sludge process (Duan et al., 2019; Li et al., 2020).

$$
\mathrm{NH}_{4}^{+}+1.5 \mathrm{O}_{2} \rightarrow \mathrm{NO}_{2-}^{-}+2 \mathrm{H}^{+}+\mathrm{H}_{2} \mathrm{O} \quad \text { Equation } 1
$$

The acidic activated-sludge process hinges on a new $A O B$ Ca. Nitrosoglobus. Ca. Nitrosoglobus was firstly described as a new phylogenetic AOB branch in 2017 , with an isolate 'Ca. Nitrosoglobus Terrae' from acidic soil samples ${ }^{10}$. Among all known ammonia-oxidisers, $\mathrm{Ca}$. Nitrosoglobus has the highest resistance to nitrite, low $\mathrm{pH}$, and FNA. These traits define $\mathrm{Ca}$. Nitrosoglobus as an adversity-strategist that tends to prosper in acidic activated-sludge, where the low $\mathrm{pH}(<5.0)$ and high levels of FNA (at parts per million levels) are sustained and inhibit all other ammonia-oxidisers.

\section{Ca. NITROSOGLOBUS ENABLES STABLE NOB SUPPRESSION UNDER MAINSTREAM CONDITIONS}

Acidic mainstream nitritation was established via $\mathrm{Ca}$

Nitrosoglobus in a $1.5 \mathrm{~L}$ laboratory-scale continuous-flow system operated for 450 days. The low-alkalinity feed for the nitritation process was created by mixing mainstream and sidestream $A D$ liquor at a volume ratio of 50:1. NOB were suppressed under $\mathrm{pH}$ at 4.5-5.0 and nitrite concentrations of 60-80 $\mathrm{mg} \mathrm{N} \mathrm{L}^{-1}$, while $\mathrm{Ca}$. Nitrosoglobus dominated the nitrifying community. Thereby, a stable mainstream nitritation process was successfully established, with a nitrite accumulation ratio (nitrite over the sum of nitrite and nitrate) of more than $95 \%$ for more than 300 days and a nitritation rate of approximate $200 \mathrm{mg} \mathrm{N} \mathrm{L}^{-1} \mathrm{~d}^{-1}$. The established nitritation process is applicable to wastewaters with a broad range of alkalinity (measured as $\mathrm{CaCO}_{3}$ ) to ammonium molar ratio (0.58-1.21). It enables autotrophic nitrogen removal in the mainstream line of municipal wastewater treatment plants, contributing to energy-neutral/positive wastewater treatment. 


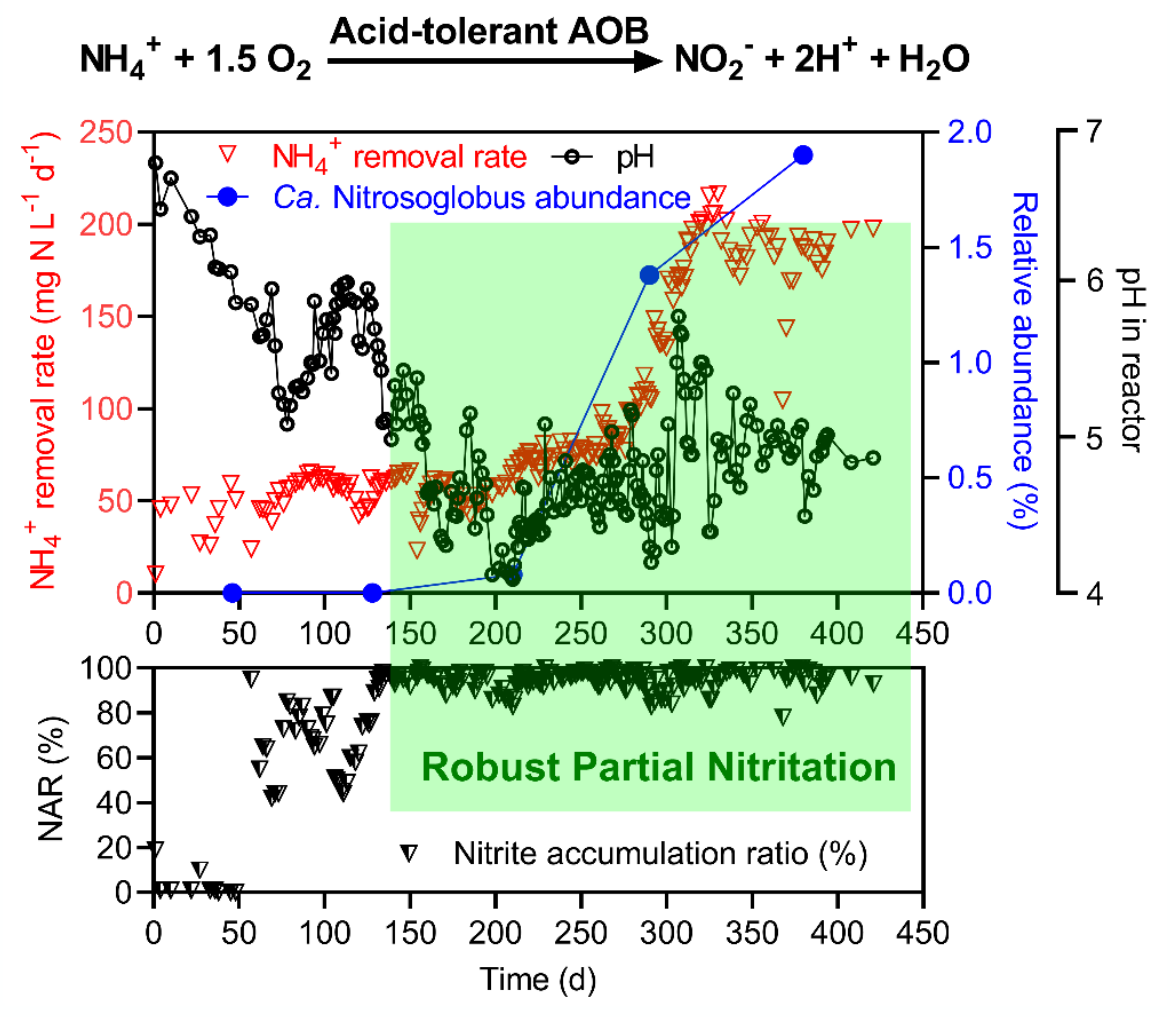

Figure 3: Stable mainstream nitritation (ammonium to nitrite) enabled by a new ammonia-oxdising bacteria (AOB) $\mathrm{Ca}$. Nitrosoglobus.

\section{Ca. NITROSOGLOBUS ENABLES REDUCTION AND STABILISATION OF AD SLUDGE}

The strong FNA resistance of $\mathrm{Ca}$. Nitrosoglobus also results in a reduction and stabilisation of $A D$ sludge in an acidic post-anaerobic aerobic digestion (PAAD) process. The acidic condition was self-sustaining by $\mathrm{Ca}$. Nitrosoglobus, by producing protons resulting from the oxidation of ammonium in $A D$ sludge. Through inoculating $\mathrm{Ca}$. Nitrosoglobus into the $\mathrm{PAAD}$, the $\mathrm{pH}$ dropped from $7.9 \pm 0.2$ in the feed sludge to $4.8 \pm 0.2$ in the PAAD reactor. At the acidic $\mathrm{pH}$, nitrite accumulated at $200.0 \pm 17.2 \mathrm{mg} \mathrm{N} \mathrm{L}^{-1}$, from which an in-situ FNA of $8.5 \pm 1.8 \mathrm{mg} \mathrm{HNO}_{2}-\mathrm{N} \mathrm{L}^{-1}$ formed. Due to the low $\mathrm{pH}$ and high FNA, the experimental reactor reduced the total solids (TS) and volatile solids (VS) by $25.2 \pm 7.0 \%$ and 29.8 $\pm 4.3 \%$, respectively (Figure 4 ). In contrast, the control reactor without $\mathrm{Ca}$. Nitrosoglobus inoculation (operated at a near-neutral $\mathrm{pH}$ of $6.8 \pm 0.3$ and no FNA formation) only reduced VS in the AD sludge by $10.4 \pm 4.3 \%$. In addition, the acidic aerobic digestion in the experimental reactor significantly stabilised AD sludge, decreasing the specific oxygen uptake rate (SOUR) to $0.5 \pm 0.1 \mathrm{mg} \mathrm{O}_{2} \mathrm{~g}^{-1} \mathrm{VS} \mathrm{h}^{-1}$ and the most probable number (MPN) of Faecal Coliforms to $2.4 \pm 0.1 \log \left(M_{P N ~ ~ g^{-1} T S}\right.$ ), both of which meet USEPA standards for Class A biosolids. In comparison, the control reactor produced biosolids at Class $B$ level only, with an SOUR of $1.8 \pm 0.2 \mathrm{mg} \mathrm{O}_{2} \mathrm{~g}^{-1} \mathrm{VS} \mathrm{h}^{-1}$ and a Faecal Coliforms MPN of $3.6 \pm 0.1 \log \left(\mathrm{MPN} \mathrm{g}^{-1} \mathrm{TS}\right)$. By reducing the volume and improving the quality of the $A D$ sludge, the acidic aerobic digestion of $A D$ sludge enabled by $\mathrm{Ca}$. Nitrosoglobus has the potential to significantly save the sludge disposal costs in wastewater treatment. 


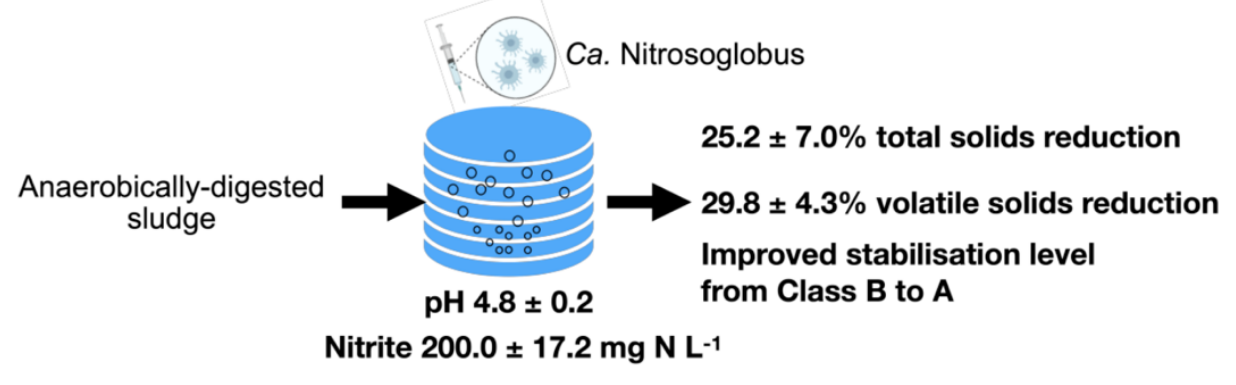

Figure 4: Reduction and stablisation of anaerobically-digested (AD) sludge enabled by a new ammonia-oxdising bacteria (AOB) Ca. Nitrosoglobus.

\section{Ca. NITROSOGLOBUS ENABLES TOXIC METAL REMOVAL FROM AD SLUDGE}

Based on the acid-tolerant property of $\mathrm{Ca}$. Nitrosoglobus, a novel bioleaching approach was developed to remove the toxic metals in AD sludge. The bioleaching is caused by the microbial oxidation of the ammonium in $A D$ sludge at a leaching-inducing $\mathrm{pH}(2-3)$ (Figure 5). A highly enriched $\mathrm{Ca}$. Nitrosoglobus consortium $(72.5 \pm 2.3 \%$ based on $16 \mathrm{~S}$ rRNA gene sequencing) was enriched after 120 days in a laboratory sequencing batch reactor. It was found that the consortium maintained ammonium oxidation even at $\mathrm{pH} 2.5$, with approximately $30 \%$ of its maximum activity (measured at the optimal $\mathrm{pH}$ of 5.5). After inoculating the consortium into $A D$ sludge, the $\mathrm{pH}$ of the $A D$ sludge decreased from 7.5 to 2.0 over a five-day aeration period, driven by the protons generated from ammonium oxidation. As a result, the metals in $A D$ sludge were extracted into the liquid phase.

Particularly, two of the most abundant metals $\mathrm{Cu}$ and $\mathrm{Zn}$ were solubilised with high efficiencies of $88 \pm 4 \%$ and $96 \pm$ $3 \%$, respectively. These results demonstrate the feasibility of metal removal from biosolids without external chemical addition, enabling an economical disposal and safe reuse of the excess sludge generated during biological sewage treatment.

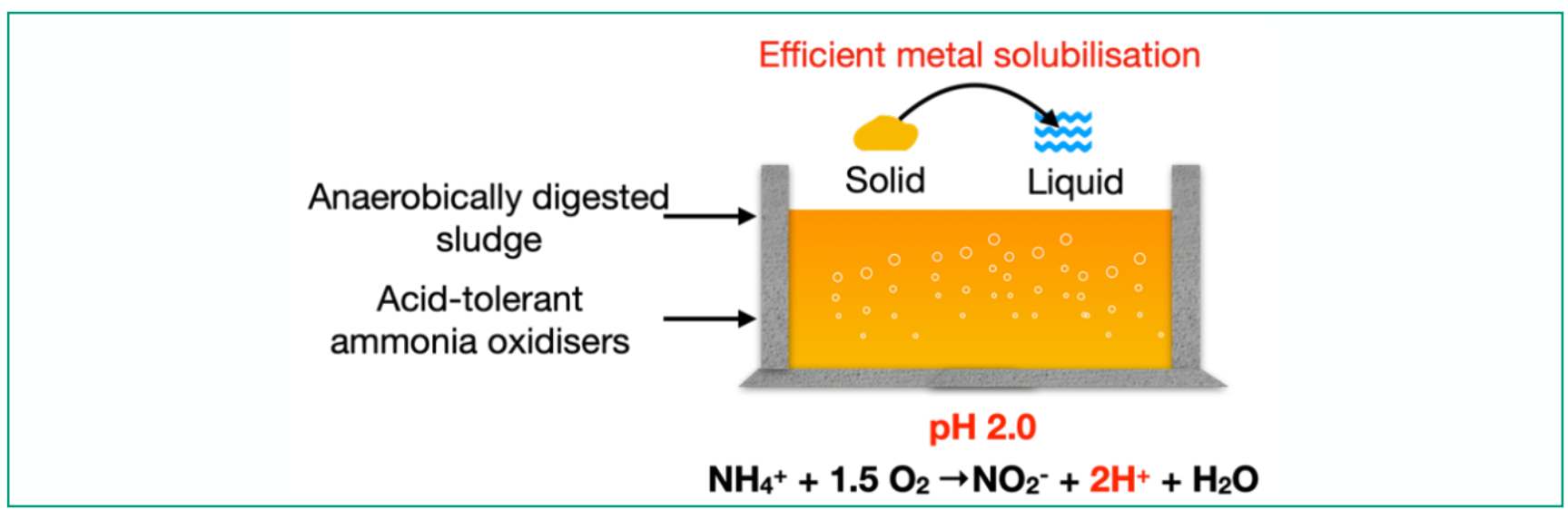

Figure 5: Efficient metal removal from anaerobically-digested (AD) sludge enabled by a new ammonia-oxdising bacteria (AOB) $\mathrm{Ca}$. Nitrosoglobus. 


\section{CONCLUSIONS}

In conclusion, this paper introduces a novel acidic activatedsludge process using a new acid-tolerant AOB Ca. Nitrosoglobus. The acidic activated-sludge process expands the operational $\mathrm{pH}$ of activated-sludge process from near neutral $(\sim 7)$ to acidic range (2-6). The acidic activatedsludge process enables multiple benefits, including maximising energy recovery, reducing sludge transportation costs, and generating Class A biosolids that qualify for unrestricted agricultural reuse. Overall, the established acidic activated-sludge process opens up new opportunities to promote the ongoing paradigm shift in WWTPs, from pollutant removal to resource and energy recovery.

\section{ACKNOWLEDGEMENT}

The author expresses sincere appreciation to Professor Zhiguo Yuan, Dr Shihu Hu, and Dr Min Zheng for their help and support. The author would also like to thank Dr. Huijuan $\mathrm{Li}$ and Mr. Shane Watts for their help to collect wastewater and sludge. The author thanks Urban Utilities for providing wastewater and sludge for this study. The author appreciates Ms Jianguang Li, Mr. Nathan Clayton, Mr. Nige Dawson, and Dr. Beatrice Keller-Lehmann for assisting with the nitrogen concentration analysis. This work was financially supported by UQ Vice-Chancellor and Deputy Vice-Chancellor's Research Strategic Initiatives Fund and District of Columbia Water and Sewerage Authority (DC Water).

\section{REFERENCES}

(1) McCarty, P. L.; Bae, J.; Kim, J. Domestic Wastewater Treatment as a Net Energy Producer-Can This Be Achieved? Environ. Sci. Technol. 2011, 45 (17), 7100-7106. https://doi.org/10.1021/es2014264.

(2) Curtis, T. P. Low-Energy Wastewater Treatment: Strategies and Technologies. Environ. Microbiol. Second Ed. 2010, 301-318.

(3) Jetten, M. S. M.; Horn, S. J.; Van Loosdrecht, M. C. M. Towards a More Sustainable Municipal Wastewater Treatment System. Water Sci. Technol. 1997, 35 (9), 171 180. https://doi.org/10.1016/S0273-1223(97)00195-9.
(4) Qiu, S.; Li, Z.; Hu, Y.; Shi, L.; Liu, R.; Shi, L.; Chen, L.; Zhan, X. What's the Best Way to Achieve Successful Mainstream Partial Nitritation-Anammox Application? Crit. Rev. Environ. Sci. Technol. 2020.

https://doi.org/10.1080/10643389.2020.1745015.

(5) Winkler, M. K. H.; Straka, L. New Directions in Biological Nitrogen Removal and Recovery from Wastewater. Curr. Opin. Biotechnol. 2019, 57, 50-55.

(6) Canales, A.; Pareilleux, A.; Rols, J. L.; Goma, G.; Huyard, A. Decreased Sludge Production Strategy for Domestic Wastewater Treatment. In Water Science and Technology; 1994; Vol. 30, pp 97-106. https://doi.org/10.2166/wst.1994.0390.

(7) Novak, J. T.; Banjade, S.; Murthy, S. N. Combined Anaerobic and Aerobic Digestion for Increased Solids Reduction and Nitrogen Removal. Water Res. 2011, 45 (2), 618-624. https://doi.org/10.1016/j.watres.2010.08.014.

(8) Li, J.; Xu, K.; Liu, T.; Bai, G.; Liu, Y.; Wang, C.; Zheng, M. Achieving Stable Partial Nitritation in an Acidic Nitrifying Bioreactor. Environ. Sci. Technol. 2019, 54 (1), 456-463. https://doi.org/10.1021/acs.est.9b04400.

(9) Duan, H.; Ye, L.; Lu, X.; Batstone, D. J.; Yuan, Z. SelfSustained Nitrite Accumulation at Low PH Greatly Enhances Volatile Solids Destruction and Nitrogen Removal in Aerobic Sludge Digestion. Environ. Sci. Technol. 2019, 53 (3), 12251234. https://doi.org/10.1021/acs.est.8b04498.

(10) Hayatsu, M.; Tago, K.; Uchiyama, I.; Toyoda, A.; Wang, Y.; Shimomura, Y.; Okubo, T.; Kurisu, F.; Hirono, Y.; Nonaka, K.; Akiyama, H.; Itoh, T.; Takami, H. An AcidTolerant Ammonia-Oxidizing $\gamma$-Proteobacterium from Soil. ISME J. 2017, 11 (5), 1130-1141.

https://doi.org/10.1038/ismej.2016.191.

\section{THE AUTHOR}

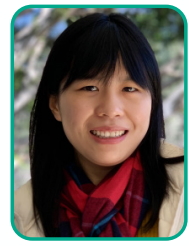

\section{Zhiyao Wang}

Zhiyao is currently a postdoctoral research fellow in The University of Queensland. She is the winner of AWA Student Water Prize 2021 for her work in energy and resources recovery from wastewater and sludge. 